\title{
High Density Chip Interconnect Technology Using High Density Glass Interposers
}

\section{Cooperative Research and Development Agreement Final Report}

\author{
CRADA Number: FRA-2017-0047
}

\section{Fermilab Technical Contact: Farah Fahim}

Summary Report

30 July 2019 


\section{NOTICE}

This report was prepared as an account of work sponsored by an agency of the United States government. Neither the United States government nor any agency thereof, nor any of their employees, makes any warranty, express or implied, or assumes any legal liability or responsibility for the accuracy, completeness, or usefulness of any information, apparatus, product, or process disclosed, or represents that its use would not infringe privately owned rights. Reference herein to any specific commercial product, process, or service by trade name, trademark, manufacturer, or otherwise does not necessarily constitute or imply its endorsement, recommendation, or favoring by the United States government or any agency thereof. The views and opinions of authors expressed herein do not necessarily state or reflect those of the United States government or any agency thereof.

Available electronically at http://www.osti.gov/bridge

Available for a processing fee to U.S. Department of Energy and its contractors, in paper, from:

U.S. Department of Energy Office of Scientific and Technical Information

P.O. Box 62

Oak Ridge, TN 37831-0062

phone: 865.576 .8401

fax: 865.576 .5728

email: mailto:reports@adonis.osti.gov

Available for sale to the public, in paper, from:

U.S. Department of Commerce

National Technical Information Service

5285 Port Royal Road

Springfield, VA 22161

phone: 800.553 .6847

fax: 703.605 .6900

email: orders@ntis.fedworld.gov

online ordering: http://www.ntis.gov/ordering.htm 
In accordance with Requirements set forth in Article $X$ of the CRADA document, this document is the final CRADA report, including a list of Subject Inventions, to be forwarded to the Office of Science and Technical Information as part of the commitment to the public to demonstrate results of federally funded research.

CRADA number: $\quad$ FRA-2017-0047

CRADA Title: $\quad$ High Density Chip Interconnect Technology Using High Density Glass Interposers

Parties to the Agreement: Collier Ventures, Inc. and Fermi Research Alliance, LLC

\begin{abstract}
CRADA work:
Modern particle physics experiments require "intelligent detectors" with dense interconnects and distributed intelligence in very large area detector systems. Available packaging and interconnect technologies directly limit the performance and capabilities of these systems. Interposers are interconnected elements that use through-silicon or through-glass via to replace the PC board technology currently used for connecting chips and can improve the interconnect density by more than two orders of magnitude. The goal of this project is to fabricate a thru glass via interposer that will allow top to bottom side interconnects in the tens of microns. Having a thru glass interposer with interconnects in the tens of microns will benefit the electrons industry which focuses on 3D packaging. In addition to commercial, medical applications such as the CAT scan, which have resolutions in the micron or larger range, will now be able to use these interposers to diagnose in the tens of microns.
\end{abstract}

\title{
Summary of Research Results:
}

CVI had to develop a process outside the original scope of the SBIR. While we can fabricate the holes as required, filling those holes hermetically is a challenge with available resources and at the temperatures required for post processing and reflow. As such, we are amending and looking towards both the 300um deep and 400um deep holes -YET- filled with ink and with polymer dielectrics we developed that can be cured at $175 \mathrm{C}$ to prevent damage to the filled vias.

\section{Related Reports, Publications, and Presentations:}

NONE

Subject Inventions listing:

NONE 
4 Final Report for CRADA FRA-2017-0047

Report Date: 9/24/2019

Technical Contact at Fermilab: Farah Fahim

This document contains NO confidential, protectable or proprietary information. 